\title{
Language Competence of HSSC Level Students in Pakistan: Developing Writing Proficiency through Literature
}

\author{
Muhammad Din ${ }^{1}$, Muhammad Asif Khan ${ }^{2} \&$ Mamuna Ghani ${ }^{3}$ \\ ${ }^{1}$ Govt. Postgraduate College Burewala, Pakistan \\ ${ }^{2}$ Department of English, The Islamia University of Bahawalpur, Pakistan \\ ${ }^{3}$ Faculty of Arts \& Islamic Learning, Chairperson Department of English, The Islamia University of Bahawalpur, \\ Pakistan \\ Correspondence: Muhammad Din, Govt. Postgraduate College Burewala, Pakistan. E-mail: mduaau@gmail.com
}

Received: December 8, 2017 Accepted: December 30, 2017 Online Published: February 4, 2018

doi:10.5539/ijel.v8n3p65 URL: http://doi.org/10.5539/ijel.v8n3p65

\begin{abstract}
Writing is a means of communication and part of everybody's education. Writing as a medium of language has its special features. This study brings to light the fact that teaching English through literature does not render any substantive and positive pay off in developing and honing the ESL/EFL learners' writing skill. In the Pakistani context, literature seems to be inadequate and improper language teaching tool at HSSC level. To achieve the set objectives of this study, the researcher went for the quantitative research methodology. So, a questionnaire comprising of four categories i.e., grammar, vocabulary, sentence structure and creative writing was designed to collect data from 600 subjects (male/female) of intermediate level. The researcher also conducted an achievement test so that a correlation might be drawn between their attitude towards "developing writing skill through literature" and the score of their achievement test. This study has also strived to categorize the subjects in accordance with their proficiency level and computed a pie chart to illustrate their proficiency level. The collected data were analyzed through software package (SPSS XX). The findings of this study explicitly reveal that the EFL learners remain unable to develop both the language skills (particularly writing skill) and language areas when they are taught English through literature. This study recommends that the teaching of English should be application oriented and task-based strategies and activities should be resorted to by the EL educators.
\end{abstract}

Keywords: writing skill, literature, ESL learners, proficiency level

\section{Introduction}

Writing is a means of communication and part of everybody's education. Writing as a medium of language has its special features. Vocabulary, grammar, semantics, signs and symbols are those fundamental features on which this tool of communication relies. Pragmatic exigencies have driven human beings to develop writing as a means of communication. In the context of globalization, writing has got imperative importance in the $21^{\text {st }}$ century. Global communication has also urged the humans of the present age to launch certain programs to sharpen the writing skills of the students of different age groups so that they may enhance their socioeconomic status. For writing is regarded as a social necessity.

Teaching facilitates the acquisition of language. It does not mean just to impart information about the target language rather it aims to enable the students to develop their language competence in such a way as they can enjoy a comprehensive command over the ESL/EFL. This end can be realized through such methodologies as can meet the multifaceted requirements of the EFL/ESL students. The problem that confronts the researcher is that the Pakistani ESL/EFL learners of Higher Secondary School Certificate level remain unable to enjoy language competence even after spending more than a decade of their academic life. There are certain problems and challenges because of which these ESL learners remain unable to develop and hone all the basic language skills listening, speaking, reading and writing. For instance, the texts chosen to this end pose difficulties at grammatical, linguistic and literal level. The literary texts do not include the structures and vocabulary previously learned and difficult and ambiguous structures also elude most of the learners of English language. The texts chosen to teach English through literature rarely deal with linguistic and grammatical sides. 


\subsection{Constituents of Language Competence}

Language competence involves interpretation and production of signed texts, the application of the knowledge of the socio-cultural context and application of the knowledge of organization, structure and sequence of discourse. Grammatical, textual, strategic and pragmatic competences are also the components of language competence. The main function of language is communication. Communication is not a simple process. It needs competence on the part of a communicator and this competence consists in a set of composite skills. Canale \& Swain (1980) consider grammatical competence, sociolinguistic competence and strategic competence the minimal components of language competence. In order to comprehend the concept of language competence i.e. the knowledge of language, it would be helpful for us to think of four circles which represent different kinds of meaning functions and the different ways of organizing such functions. The knowledge of these areas helps the communicator to carry out communication in an appropriate and effective way.

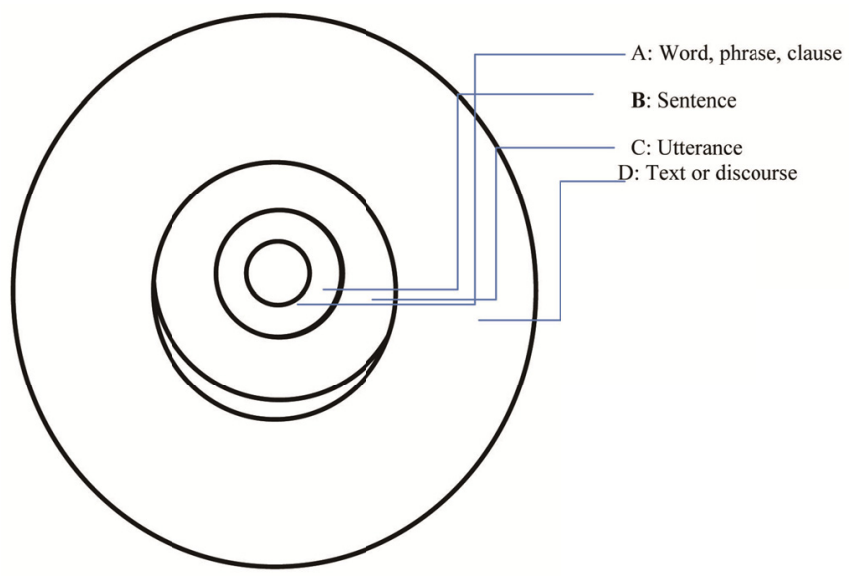

Figure 1. Constituents of language learning

Figure 1 represents those four ingredients of language competence over which an ESL/EFL learner must have a comprehensive command. The notional or conceptual meaning of a lexical item is represented by the first Circle (A). Here, the basic meaning category of grammar is found and learnt as the first step towards communicative competence. Words, phrases and clauses are those structural units which are dealt with at this stage. The Circle "B" represents the logical aspects of communication. The categories like statements, questions, responses affirmations, denial, possibility, and certainty are the part of this phase. In other words, "sentence" is the chief concern of a learner's here. The third aspect of the language knowledge i.e., the social dimension of communication is represented by the Circle "C". At this stage, grammar is related to the attitudes and behavior of the speaker as well as of the hearer's. Here, language is the means of carrying out social ends as the speaker expresses his attitudes and emotions while the actions and attitudes of the listener can be controlled and influenced by means of language. Through the speech acts like commanding, requesting, advising and promising, the "controlling" aspect of communication is carried out by making use of the logical aspect of meaning (Circle B) so that social functions of different kinds can be performed. So, as we know, a question is made to seek some information but the same question can made, pragmatically, for making an offer "Would you like a cup of coffee?" or making a suggestion "Why don't you go for Ph.D.?" or expressing a strong feeling "Isn't she a nice lady?" Circle D deals with how thoughts are arranged, put in order, and bound together so that communication can be carried out in a most appropriate and effective way. In such cases, a considerable choice is offered by grammar. In other words, we may say that this level of communicative competence takes account of the organization of communication and context. Here, a student of foreign language learns how to communicate in a specific situation and how to look at an utterance not in isolation but in a unit i.e., text or discourse. Apart from these aspects of language competence, a learner of EFL must also be well-versed with the levels of usage. They may include formal and informal, polite and familiar, impersonal style, tactful and tentative and literary and rhetorical. It is very much imperative for the ESL/EFL learners to comprehend and have full command over these levels so that they may make an appropriate use of English grammatical forms and structures.

\subsection{Significance of English in Pakistan}

English has become an international language or an "international lingua franca". It has achieved such a status as is recognized by every country across the world. In Pakistan, English occupies a place of honor and prestige 
among the languages spoken here. In recent times, owing to the remarkable success of the English-speaking nations in the fields of industry and politics, the people, governments, and institutions have steered their focus and interest towards this language. It has generally been observed that strong language competence renders students good pedestal and they get entry into higher institutions as the learning of English language wields so much intense importance in Pakistan in the present scenario. English has also become the symbol of education and an elite status in the Pakistani society and has become the language of media, science, technology and a means of inter-national as well as intra-national communication. Ghani (2003) styles this language "a gateway to success" in Pakistan. Akram \& Mehmood (2007) have analyzed the factors which motivate the Pakistani students to go for the learning of English language. They claim that the motivational factors like studies abroad, greater job opportunities, social or missionary aspirations, better economic prospects and academic ends make them learn this language.

\subsection{Teaching of English as a Second/Foreign Language in Pakistan}

English is a compulsory subject up to graduation level in Pakistan but it has been observed that even after spending a lot of time in learning English, majority of school and college students are unable to write grammatically correct English. It has been observed that the teaching of English in Pakistan, specifically in state-run schools and colleges, is highly ritualized. Seldom do the students focus on learning English when they are mentally obsessed in learning texts for the sake of its reproduction. According to Coleman (2012), the reproduction of set texts and the provision of memorized written answers to questions about those texts mean that the teaching of English neglects speaking, listening and critical reading which are termed as the integral features of language competence. Akram \& Mehmood (2007) have also analyzed and enumerated some of the problems and challenges which are being faced in teaching English as a foreign language in Pakistan. A very pertinent and relevant issue regarding the teaching of English as a foreign language in Pakistan has been raised by them is that of medium i.e., literature. They seem to be convinced that this medium of teaching English language is inadequate to impart the required competence among the learners of this language.

\subsection{Significance of the Study}

This study will help the syllabus designers, policy makers and other stake holders to gauge the importance of literature in the teaching of English language. It will stimulate the other researchers and particularly the teachers of English language at college level to reflect on the issue how the teaching of English can be made more effective and fruitful for the sake of the learner's benefit. The present study will also make a meaningful contribution in appreciating the problems faced by those students who learn English through literature. This study will bring the fact to light how much literature caters to the linguistic needs of the learner of English and positively contribute in the field of ELT in the Pakistani context.

\subsection{Objectives of the Study}

The present study has following objectives to achieve.

1) To know what is the level of the ESL learners' language competence.

2) To know the ESL/EFL learners' attitude towards teaching and learning English through literature.

3) To analyze to what extent classroom tasks play a role in developing English language competence.

4) To identify the problems faced by the students in acquiring language competence while learning English as second language.

\subsection{Research Questions}

1) What is the level of the ESL learners' language competence?

2) What is the ESL learners' attitude towards teaching and learning English through literature?

3) What extent do the classroom tasks play a role in developing English language competence?

4) What problems are faced by the students in acquiring language competence while learning English as second language?

\section{Literature Review}

There appears to be a positive correlation between the teaching strategies and language competence. The purpose behind the teaching of English as a foreign language is to generate and develop language competence which is an imperative skill in the present day world. But, in Pakistan particularly in state-run schools and colleges, the methodology adopted for the teaching of English as a second/foreign language has failed miserably in developing the required competence among the learners of this language. Ahmad \& Rao (2013) have conducted 
an empirical study in the same context. Their study expresses their dissatisfaction regarding the traditional methodology (GTM) of teaching English as a foreign language because of its failure in fostering the required competence in the learners of the target language.

Kunwar (2013) lays stress on creating opportunities for the interaction of the EFL learners with quality literature. While reflecting on the practices being carried on in Indian classrooms, the researcher presents a very saddening side of the picture regarding the use of literature in the language classroom. These facts also come true in the Pakistani context, too. While reflecting on the prevalent practice in the Indian context, Kunwar (2013) quite aptly maintains that a highly mechanical and conventional approach is adopted towards literature in the language classroom, teacher reads and explains each and every line of the text, students are expected to scan the text so as to get information for the sake of the exam and they are expected to cram the answers to the questions given at the end of a lesson. Thus the basic aspects of language skills and language areas are neither dealt with nor developed because of this.

Another problem mentioned by Akram \& Mehmood (2007) is that the method adopted for the teaching of English is that of Grammar Translation Method (GTM) which is quite outdated and obsolete. Apart from these challenges, the lack of teacher training, old text books, promotion of cramming, provision of ready-made material, faulty examination system, no use of Audio Visual Aids, and overcrowded class rooms are also such challenges as have proved a formidable impediments in the effective and successful teaching of English as a foreign language in Pakistan.

One of the dilemmas of teaching English through textbooks in Pakistan is that the foreign language teachers (FLT's) teach only the standard forms of the target language and these forms are far away from the native speakers' experience. Thus, such an approach on the part of the foreign language teachers deprives the ESL/EFL learners of the absolute diversity and function of the linguistic expression in the society where the target language is spoken. As a result of this TEFL methodology, not only do the students not understand the real nature of the target language but they also do not know how it functions in the native society. Aghagolzadeh \& Tajabadi (2012) believe that when a learner is studying FL text books just to gain maximum marks, it becomes very difficult, if not impossible, to socialize and identify himself with the target culture.

Deeba \& Sultana (2008) also point out that a large number of students who study English as a second/foreign language are not very familiar with the Standard English language. That is why they have least mastery over analytical thought and also constructing rhetorical sentences. They also maintain that the application of this teaching resource needs the selection of texts in literature which have clarity and acceptance to the SL/FL learners. If the FL learner is not in touch with the trunk of this language, he/she can in no way have the mastery over it.

The primary requisite for communication in a foreign language is the functional use of it. After acquiring communicative competence, the EFL learners become able to express their feelings, desires, needs and attitudes in that language. It is very important for the ESL/EFL learners to get access beyond the form and structure of language and exploit different input from the typical course book to enjoy effective, comprehensive and motivating communication. As traditional FL text books and course books don't help the EFL learners achieve these cherished ends. The teaching and practice of grammatical forms and structures are the basic components of grammar-based syllabus where the focus is always on grammatical form and structure and vocabulary so that the learners may express themselves.

Premawardhena (2006) has explored the perspective and challenges in the integration of literature in the teaching of foreign language with a specific reference to Sri Lanka. Premawardhena (2006) shares with us that the integration of literature in curriculum causes certain problems like literary criticism, appreciation, comprehensibility and accessibility. Owing to these challenges, the ESL/EFL learners have to face a variety of challenges in achieving language competence. These problems include their dependence on notes, hesitation to articulate an opinion and inability to analyze and criticize any piece of text.

Khatib, Derakhshan, \& Rezai (2011) propound in their study that it is the primary duty of those teachers who teach English as a second/foreign language to facilitate and assist the ESL/EFL learners achieve communicative competence in the target language. Some scholars believe that the EFL learners can master the form, structure, pragmatics and semantics of the foreign language with the help of literature and literary texts. But the researchers believe that some of the teachers are not well conversant with the implementation of those texts, procedures and techniques which can be helpful in the teaching of English as a foreign language.

According to Daskalovska \& Dimova (2012), grammatical, strategic and sociolinguistic competence constitutes the ultimate end in ELT. They believe that FL text books present only the referential material for the learning of 
the foreign language. Through these text books, the SL/FL learners are given only the explicit information. For instance, the FL learners can grasp only the denotative meanings of the lexical items and they don't find any exposure to figurative language. The present researcher also agrees with them in this respect as the EFL learners at Intermediate Level are confined to the mere text books which they are supposed to mug up and reproduce them in the examination hall. Thus, they neither enjoy the opportunity of imaginative involvement nor self-expression in the target language.

Cruz (2010) believes that language is not mere "words, words, words". It is a source of receiving and transmitting many things like routines, habits, traditions and economic and social contexts. While discussing the role of literature and culture in the teaching of English language, the researcher says that at undergraduate level literature and culture act as a bridge between the EFL learners and the soul of the target language. According to Cruz, text books provide artificial grammar in a language classroom and it establishes an atmosphere of static nature. As a result, the EFL learners, according to the researcher, learn a "nowhere English" which has an artificial standard. This sort of English helps the EFL learners communicate with the native speakers just on a "survival level".

Cruz (2010) also believes that the EFL learners remain devoid of the exposure to the "language in use" which can bestow them with an opportunity to use the language which is developed by the linguistic as well as rhetorical uses of that very language and they can also be provided with various forms, conventions and standards of written language mode. This "language in use" lands the EFL learners in a specific geopolitical context which isn't done through text books whereas through the "language in use", the EFL learners are exposed to the way language is spoken and written in a certain geopolitical context by the literary works. In this way, a closer relationship is developed when the EFL learners go through a personal and social experience after reconstructing the language for themselves and on their own.

Reinders \& Balkicanli (2011) have concluded that text books do not help the EFL learners to achieve the target of self-directed learning in the target language. According to them, the results of their study show that the textbooks investigated by them have not included the focus on learning strategies which can steer the EFL learners towards the goal of self-directed learning.

Harlan (2000) thinks that there is a missing link between second language acquisition (SLA) theory and pedagogical practice. Various methodological approaches can be resorted to for the presentation of linguistic concepts given in the FL textbooks. In order to prove a very close relation between different theories of second language acquisition and the pedagogical methods, practices and strategies, the researcher has discussed certain theories of language acquisition as well as language learning. The researcher has discussed certain learning theories like behaviorism, innatism and interactionism. He has also shed light on some methodological approaches. He believes that the methodology for the classroom pedagogy adopted by the instructor bears a profound impact of the learning theory. The researcher seems to be pretty sure that these two concepts enjoy a connecting relationship in the teaching of a foreign language.

Pathan \& Al-Dersi (2013) have conducted a study in the Libyan EFL learners' context regarding the problems which they have to face in their reading comprehension skill. This study unearths the problems like ineffective communication, deficiency of vocabulary, incorrect pronunciation, and violation of punctuation norms and comprehension of the text. The researchers believe that the Libyan EFL learners have to face these challenges because of the nuances caused the foreign language i.e., English. They also believe that the incorporation of the short stories in the teaching of English as a foreign language can provide the remedial material to these challenges faced by the Libyan EFL learners if these short stories are selected and used as teaching resource with useful and effective pedagogical strategies and activities.

Pardede (2011) focuses on how short stories can be used to enhance the EFL learners' language skills and communicative competence. This study also emphasizes that linguistic and cultural elements should be given due focus in the selection of the short stories which can be used as a teaching resource. It is also recommended by this study that a teacher design and use such activities in the language class as can be helpful for the development of the EFL learners' language skills.

\section{Research Methodology}

This study is primarily quantitative in nature. So, the researcher has gone for the quantitative research methodology. According to Dornyei (2011), "quantitative research involves data collection procedures that result primarily in numerical data which is then analyzed primarily by statistical methods." Typical example: survey research using a questionnaire, analyzed by statistical software such as SPSS. 


\subsection{Population and Subjects of the Study}

The population of this study is all the intermediate students of the Punjab. The subjects of the present study are 600 (male and female) students of intermediate level of different colleges of Pakistan.

\subsection{Research Instruments}

The research instruments of this study are a questionnaire and an achievement test.

\subsubsection{Questionnaire}

To obtain data from the sample of the study, a questionnaire consisting of four sections i.e. grammar, vocabulary, sentence structure and creative writing and sixty questionnaire items was constructed so that the maximum aspects of the major areas of language competence might be encompassed. All the questionnaire items of this research instrument are close-ended in Likert scale and the respondents have been asked to mark their response from "strongly agree" to "strongly disagree".

\subsubsection{Achievement Test}

In order to draw a correlation between the participants' attitude towards teaching English (through literature) and their achievement test score, the researcher has conducted an achievement test on the pattern of "TOEIC Writing Test" in accordance with the context of the Pakistani ESL/EFL learners. This achievement test primarily consisted of three questions. The first question was comprised of five pictures in which below every picture were two words which the subjects were to use in their sentence to describe the picture. They might change the form of the words to suit the grammar of their sentence. The second question consisted of two Respond-to-a-Written questions and the third question was one "Write-an-Opinion-Essay" in which the subjects were to write an essay to state, explain and support their opinion on an issue. The achievement test carried 25 marks of which 10 were allocated to each question. This achievement test consists of nine language competence levels on the basis of scaled score. The maximum scaled score of this test is 200 which have been got by multiplying the total marks (30) of the test with 8 . The scaled score and its corresponding language competence level have been given in a table as follows:

Table 1. Scaled score and language competence level

\begin{tabular}{ll}
\hline Scaled Score & Competence Level \\
\hline $191-200$ & 9 \\
$171-190$ & 8 \\
$141-170$ & 7 \\
$111-140$ & 6 \\
$91-110$ & 5 \\
$71-90$ & 4 \\
$51-70$ & 3 \\
$31-50$ & 2 \\
$00-30$ & 1 \\
\hline
\end{tabular}

The response of the subjects was scored on the parameters of vocabulary, grammar, relevance of sentence to picture, quality and variety of sentences, organization and creative writing.

\section{Results and Discussion}

Table 2. ESL/EFL learners' attitude towards teaching English grammar through literature

\begin{tabular}{|c|c|c|c|c|c|c|c|c|}
\hline S. No. & Questionnaire Items & SA & A & $\mathrm{N}$ & DA & SDA & Mean & $\mathrm{SD}$ \\
\hline 1 & $\begin{array}{l}\text { The literature I am taught does not help me understand all } \\
\text { about noun. }\end{array}$ & 54 & 318 & 4 & 200 & 24 & 3.3 & 1.139 \\
\hline 2 & Count and non-count nouns cause problem to me. & 46 & 315 & 25 & 181 & 33 & 3.27 & 1.133 \\
\hline 3 & I do not learn the change of pronouns in English class. & 53 & 288 & 14 & 194 & 51 & 3.16 & 1.213 \\
\hline 4 & $\begin{array}{l}\text { I cannot easily make a distinction between adjective and } \\
\text { adverb after going through the lessons of my text book. }\end{array}$ & 73 & 311 & 11 & 177 & 28 & 3.37 & 1.162 \\
\hline 5 & $\begin{array}{l}\text { The comprehension and use of adverbs create problem for } \\
\text { me. }\end{array}$ & 86 & 369 & 5 & 114 & 26 & 3.63 & 1.078 \\
\hline 6 & $\begin{array}{l}\text { With the help of my text books, I learn about the } \\
\text { conjunctions and their correct use. }\end{array}$ & 56 & 220 & 18 & 253 & 53 & 2.95 & 1.231 \\
\hline
\end{tabular}




\begin{tabular}{|c|c|c|c|c|c|c|c|c|}
\hline 7 & $\begin{array}{l}\text { I do not learn thoroughly the use of articles after having } \\
\text { gone through the book. }\end{array}$ & 78 & 317 & 8 & 177 & 20 & 3.43 & 1.139 \\
\hline 8 & $\begin{array}{l}\text { Prepositions and their use remain no longer a problem for } \\
\text { me when I have learnt my lesson. }\end{array}$ & 47 & 203 & 6 & 265 & 79 & 2.79 & 1.256 \\
\hline 9 & $\begin{array}{l}\text { I buy a helping book to comprehend the grammatical } \\
\text { aspects of language. }\end{array}$ & 242 & 314 & 2 & 32 & 10 & 4.24 & .844 \\
\hline 10 & $\begin{array}{l}\text { I do not learn the correct usage of the tenses while reading } \\
\text { the text books. }\end{array}$ & 119 & 326 & 3 & 127 & 25 & 3.64 & 1.141 \\
\hline 11 & $\begin{array}{l}\text { I face no difficulty in maintaining subject-verb agreement } \\
\text { after having gone through my text books. }\end{array}$ & 19 & 131 & 8 & 318 & 124 & 2.34 & 1.125 \\
\hline 12 & $\begin{array}{l}\text { I also learn the auxiliary verbs and their usage with the } \\
\text { help of my text books. }\end{array}$ & 82 & 343 & 7 & 148 & 20 & 3.53 & 1.103 \\
\hline 13 & I face problem in the use of causative verbs. & 169 & 315 & 22 & 77 & 17 & 3.9 & 1.039 \\
\hline 14 & $\begin{array}{l}\text { I always answer the question in the same tense in which it } \\
\text { is asked. }\end{array}$ & 67 & 197 & 7 & 261 & 68 & 2.89 & 1.286 \\
\hline 15 & $\begin{array}{l}\text { While reading the text book, I do not learn how to change } \\
\text { the narration. }\end{array}$ & 137 & 336 & 8 & 104 & 15 & 3.79 & 1.058 \\
\hline 16 & I experience difficulty in changing the voice of a sentence. & 108 & 327 & 11 & 129 & 25 & 3.61 & 1.132 \\
\hline 17 & $\begin{array}{l}\text { In English class, I do not learn how auxiliary verbs are } \\
\text { used in making interrogative sentences. }\end{array}$ & 55 & 281 & 8 & 207 & 49 & 3.14 & 1.22 \\
\hline 18 & Tag questions are taught in English class. & 136 & 269 & 12 & 151 & 32 & 3.54 & 1.236 \\
\hline 19 & I am not familiar with the concept of ellipsis in language. & 115 & 264 & 15 & 175 & 31 & 3.43 & 1.235 \\
\hline 20 & $\begin{array}{l}\text { The prosodic features are also focused during my studying } \\
\text { a piece of text. }\end{array}$ & 59 & 152 & 11 & 257 & 121 & 2.62 & 1.319 \\
\hline
\end{tabular}

Table 2 shows the ESL/EFL learners' attitude towards teaching English grammar through literature. The results of the present study also show that the learning, practice and use of the grammatical aspects are the most neglected area in the teaching of English through literature. The parts of speech and their usage are rarely discussed, practiced and tested in the language classroom. It has been found that $64 \%$ of the respondent can't make a distinction between adjective and adverb whereas $75.8 \%$ EFL learners face problems in the use of adverbs. The level of the EFL learners' grammatical competence can be estimated from the fact that $92.6 \%$ students buy guide books to learn the grammar and the grammatical aspects of English language. Moreover, $73.7 \%$ EFL learners face the problem of subject-verb agreement when they learn language through textbooks and $81 \%$ of them face problem in the use of causative verbs. This finding of the present study is also seconded by a case study conducted by Nayan (2009) who has found out that after spending almost 12 years, the EFL learners remain unable to maintain subject-verb agreement in their expressions. In the same way, Shuib (1991) also finds out that the subject-verb agreement is one of the most challenging problems which are faced by the Malaysian EFL learners. Moreover, Dorn (2000) seems to be convinced of the significance of subject-verb agreement for mastering the grammar of the target language. Likewise, Aghagolzade \& Tajabadi (2012) have also strived to dig out the causes behind this pitfall faced by the EFL learners. As far as the change of narration is concerned, $78.8 \%$ do not find themselves able to do this. . In this respect, these findings of the present study relate to those of Sakthivel \& Kavidha (2010) who lament that language acquisition is purely theoretical not application-oriented. In this respect, the findings of this study are also seconded by those of the study conducted by Mckay (1982) who expresses the same reservation regarding the role of literature in the teaching of grammar. In his study, he maintains that literature lacks contribution to the teaching of grammar. The present study relates to Ansari's (2013) in which he propounds the same thing while rounding off his study that the literature taught to the EFL learners is not supported with grammar-oriented exercises which can be done in the language classroom to practice the grammatical aspects of the language. Ansari (2013) believes that the current practices in teaching literature to the EFL learners seem to encourage content-based and memory-oriented study of literature.

Table 3. Correlation between achievement test and ESL learners' attitude towards teaching grammar through literature

\begin{tabular}{lll}
\hline & Grammar & Achievement Test \\
\hline Pearson Correlation & 1 & $1.000^{* *}$ \\
Sig.(2-tailed) & & .000 \\
$\mathrm{~N}$ & & 600 \\
\hline
\end{tabular}

Note. **. Correlation is significant at the 0.01 level (2-tailed). 
Table 3 shows that there is a significant positive correlation between the ESL learners' attitude towards teaching grammar through literature and the achievement test $(\mathrm{r}=1.000, \mathrm{p}<.01)$.

Table 4. ESL/EFL learners' attitude towards teaching English vocabulary through literature

\begin{tabular}{|c|c|c|c|c|c|c|c|c|}
\hline S. No. & Questionnaire Items & SA & A & $\mathrm{N}$ & $\mathrm{D}$ & SDA & Mean & SD \\
\hline 1 & $\begin{array}{l}\text { I can easily comprehend the contextual meaning of the } \\
\text { lexical items used in the text. }\end{array}$ & 141 & 375 & 6 & 65 & 13 & 2.96 & 1.312 \\
\hline 2 & $\begin{array}{l}\text { Only the synonyms of the lexical items used in the text } \\
\text { are tested in the exams. }\end{array}$ & 119 & 347 & 18 & 96 & 20 & 3.94 & .934 \\
\hline 3 & $\begin{array}{l}\text { I cannot detect the connotative meaning of the used } \\
\text { lexical item in the text. }\end{array}$ & 25 & 164 & 9 & 279 & 123 & 3.75 & 1.052 \\
\hline 4 & I learn through text how words change their forms. & 34 & 154 & 6 & 275 & 131 & 2.48 & 1.208 \\
\hline 5 & $\begin{array}{l}\text { During the reading of text books, I give due importance } \\
\text { to homonyms. }\end{array}$ & 118 & 282 & 10 & 145 & 45 & 2.48 & 1.242 \\
\hline 6 & $\begin{array}{l}\text { While teaching a piece of literature, idiomatic } \\
\text { expressions and their usage are not always discussed. }\end{array}$ & 122 & 379 & 00 & 72 & 27 & 3.47 & 1.256 \\
\hline 7 & $\begin{array}{l}\text { The reading of the text books always helps me in } \\
\text { enhancing my word bank. }\end{array}$ & 130 & 302 & 10 & 120 & 38 & 3.83 & 1.03 \\
\hline 8 & $\begin{array}{l}\text { In text books, I do not get access to many words of } \\
\text { spoken and written material in modern English. }\end{array}$ & 65 & 232 & 16 & 239 & 48 & 3.61 & 1.206 \\
\hline 9 & $\begin{array}{l}\text { I always focus on the pronunciation of new lexical items } \\
\text { when they become the part of my word bank. }\end{array}$ & 34 & 217 & 10 & 266 & 73 & 3.05 & 1.241 \\
\hline 10 & $\begin{array}{l}\text { Contracted forms are practiced when I come across them } \\
\text { in text books. }\end{array}$ & 102 & 243 & 12 & 182 & 61 & 2.79 & 1.215 \\
\hline 11 & $\begin{array}{l}\text { Punctuation is always focused during the teaching of a } \\
\text { lesson. }\end{array}$ & 108 & 308 & 13 & 132 & 39 & 3.24 & 1.32 \\
\hline 12 & $\begin{array}{l}\text { Through literature, I do not learn how to make } \\
\text { appropriate linguistic of lexical items according to the } \\
\text { situation I am in. }\end{array}$ & 63 & 205 & 11 & 275 & 46 & 3.52 & 1.201 \\
\hline 13 & $\begin{array}{l}\text { I get a comprehensive command over my spellings in the } \\
\text { language class. }\end{array}$ & 147 & 333 & 6 & 99 & 15 & 2.94 & 1.235 \\
\hline 14 & $\begin{array}{l}\text { I have to use dictionary to look up the meaning of lexical } \\
\text { items used in the text. }\end{array}$ & 23 & 152 & 8 & 254 & 163 & 3.83 & 1.055 \\
\hline 15 & $\begin{array}{l}\text { In English class, the teacher teaches vocabulary through } \\
\text { different activities. }\end{array}$ & 120 & 362 & 10 & 94 & 14 & 2.36 & 1.23 \\
\hline
\end{tabular}

Table 4 shows the $83.5 \%$ of the subjects' claim that the reading of the textbooks always helps them enhance their word bank. In order to unearth the role of literature particularly that of the short-stories in building the EFL learners' vocabulary, Al-Dersi (2013) has also conducted a study in which he demonstrates that short-stories promote an elementary grasp of English to internalize vocabulary and an extensive reading increases vocabulary level of the EFL learners. He rounds off his study by maintaining that short-stories are a powerful pedagogic tool in order to promote EFL learners' vocabulary development by making the process more enjoyable and meaningful. He also claims that this linguistically rich device needs adequate attention and strategy in any program of vocabulary teaching. The present study also demonstrates that $80 \%$ subjects of this study claim that the teaching of English through literature also motivates the EFL learners to use dictionary to look up the meaning of the unknown lexical items of their textbooks. The present study has also brought to light the fact that only the synonyms are asked in the class and the examination hall. It has been corroborated by $86 \%$ of the subjects of the present study. Nam (2010) highlights the significance of the teaching and learning of vocabulary in the ESL context when he claims that the learning of vocabulary paves the way for the honing of the language skills. He considers the poor vocabulary an impediment to the effective learning of English language. Harmon et al. (2009) claim that it is an on-going process in which the EFL learners encounter new words used in a meaningful and comprehensible text. Recognizing the significance of different classroom activities and strategies to enhance the EFL learners' vocabulary, Halstijn \& Laufer (2001) maintain that the EFL learners should go for composition tasks because they ensure the retention of the target vocabulary items. They are also of the opinion that those students who engage themselves in composition tasks i.e., "vocabulary production processing" remember the vocabulary items better than those learners who don't. The same strategy for the better and longer retention of vocabulary has also been suggested by Lee \& Muncie (2006). 
Table 5. Correlation between achievement test and ESL learners' attitude towards teaching vocabulary through literature

\begin{tabular}{lll}
\hline & Vocabulary & Achievement Test \\
\hline Pearson Correlation & 1 & $.166^{* *}$ \\
Sig.(2-tailed) & & .000 \\
$\mathrm{~N}$ & & 600 \\
\hline
\end{tabular}

Note.**. Correlation is significant at the 0.01 level (2-tailed).

Table 5 shows that there is a positive correlation between the ESL learners' attitude towards teaching vocabulary through literature and the achievement test $(\mathrm{r}=.1666, \mathrm{p}<.01)$.

Table 6. ESL/EFL learners' attitude towards the teaching of sentence structure through literature

\begin{tabular}{|c|c|c|c|c|c|c|c|c|}
\hline S. No. & Questionnaire Items & SA & $\mathrm{A}$ & $\mathrm{N}$ & $\mathrm{DA}$ & SDA & Mean & SD \\
\hline 1 & $\begin{array}{l}\text { While reading text, I do not become able to recognize } \\
\text { the different kinds of phrases. }\end{array}$ & 120 & 362 & 10 & 94 & 14 & 3.8 & 1.007 \\
\hline 2 & $\begin{array}{l}\text { I can comprehend and use those phrasal verbs which I } \\
\text { have learnt from my text books. }\end{array}$ & 21 & 171 & 17 & 296 & 95 & 2.55 & 1.161 \\
\hline 3 & $\begin{array}{l}\text { I do not fully understand the constituents and kinds of a } \\
\text { clause used in the text. }\end{array}$ & 105 & 341 & 13 & 125 & 16 & 3.66 & 1.074 \\
\hline 4 & $\begin{array}{l}\text { I cannot learn about the structure of sentence in English } \\
\text { class. }\end{array}$ & 95 & 305 & 7 & 167 & 26 & 3.46 & 1.176 \\
\hline 5 & $\begin{array}{l}\text { I can easily determine whether the sentence is in } \\
\text { indicative or interrogative mood after I have learnt my } \\
\text { lesson well. }\end{array}$ & 92 & 360 & 5 & 110 & 33 & 3.61 & 1.115 \\
\hline 6 & $\begin{array}{l}\text { Text books do not supply essential information about } \\
\text { grammatical form and structures. }\end{array}$ & 143 & 318 & 13 & 100 & 26 & 3.75 & 1.122 \\
\hline 7 & $\begin{array}{l}\text { The literature that is taught describes and exemplifies } \\
\text { both types of language use i.e. spoken and written. }\end{array}$ & 28 & 124 & 9 & 289 & 150 & 2.32 & 1.189 \\
\hline 8 & $\begin{array}{l}\text { I face a problem in the construction of conditional } \\
\text { sentences. }\end{array}$ & 91 & 376 & 10 & 97 & 26 & 3.68 & 1.051 \\
\hline 9 & $\begin{array}{l}\text { I find myself at ease in rendering a passage from Urdu } \\
\text { into English and vice versa. }\end{array}$ & 41 & 119 & 4 & 297 & 139 & 2.38 & 1.228 \\
\hline 10 & $\begin{array}{l}\text { While reading text, I do not learn about the simple, } \\
\text { complex and compound sentences. }\end{array}$ & 124 & 338 & 9 & 108 & 21 & 3.73 & 1.088 \\
\hline
\end{tabular}

Table 6 consists of ten questionnaire items regarding the ESL/EFL learners' attitude towards the teaching of sentence structure. When we have a look at the aggregate response extended by the subjects of this study, we find out that $54.69 \%$ of the respondents have agreed while $19.19 \%$ respondents have strongly agreed that they remain unable to get insight into and the practice of different aspects of English sentence structure. It is interesting to note that $75.3 \%$ of the respondents claim that after learning their lesson well, they can determine whether the sentence is in indicative or interrogative mood. It has also been found out that $73.88 \%$ respondents show their agreement that sentence structure and its different aspects are not focused during their being taught English. The present study also explores the fact that the syntactical aspects of the target language remain untapped in the teaching of English through literature at intermediate level. For instance, $77.9 \%$ of the respondents claim that they face problem in the construction of conditional sentences. In the same way, $72.7 \%$ subjects of the study respond that they do not feel themselves at ease in rendering a passage from Urdu into English and vice versa. It is an open secret that the EFL learners remain unaware of the different elements of sentence and its types. Through their textbooks, they do not get any idea about clause, simple, compound or complex sentences. These findings of this study relate to and are seconded by the study conducted by Salsbury (2012) who has also raised voice in this regard when he claims that the EFL learners do not get any chance to "personalize the writing activities" when they are kept engaged in merely grammar tasks and pattern practices. The same opinion has been expressed by Mashori \& Lal (2011) who maintain that writing a grammatically correct sentence does not mean the ability to write a convincing and logical essay because this skill demands much more than this. It has also been found out that $77 \%$ of the respondents do not learn about simple, compound and complex sentences in the language class. All these facts reveal that syntax and syntactical aspects of the target language are the most ignored area of language teaching and learning through literature. The same 
findings have also been reached at by Leki \& Carson (1994) who opine that the mastery of syntax and written grammar are two distinct features as it involves the acquisition of the acceptable English rhetoric. Another study conducted by Bhatia (1999) and Boshar (1998) also propounds the same view that training and practice are the major requisites for the creation of the "unified whole". The same opinion has been shared by Swales and Feak (1994) when they suggest that apart from teaching textbooks and the literature embodied in them, training and practice are must for developing the EFL learners' writing skill.

Table 7. Correlation between achievement test and ESL learners' attitude towards teaching sentence structure through literature

\begin{tabular}{lll}
\hline & Sentence Structure & Achievement Test \\
\hline Pearson Correlation & 1 & .033 \\
Sig. (2-tailed) & & .418 \\
$\mathrm{~N}$ & & 600 \\
\hline
\end{tabular}

Table 7 shows that there is positive correlation between the ESL learners' attitude towards teaching sentence structure and achievement test but this correlation is not significant.

Table 8. ESL/EFL learners' attitude towards teaching creative writing through literature

\begin{tabular}{|c|c|c|c|c|c|c|c|c|}
\hline S. No. & Questionnaire Items & $\mathrm{SA}$ & $\mathrm{A}$ & $\mathrm{N}$ & DA & SDA & Mean & SD \\
\hline 1 & The text books do not help me in my creative writing. & 135 & 305 & 7 & 137 & 16 & 3.68 & 1.135 \\
\hline 2 & $\begin{array}{l}\text { I find it difficult to render a satisfactory answer to a } \\
\text { question even when I have not crammed it. }\end{array}$ & 173 & 341 & 4 & 63 & 19 & 3.98 & 1.001 \\
\hline 3 & $\begin{array}{l}\text { When I am going through the text, I do not learn lexical } \\
\text { appropriateness. }\end{array}$ & 95 & 403 & 8 & 82 & 12 & 3.81 & .93 \\
\hline 4 & $\begin{array}{l}\text { I don't get a good deal of information about American } \\
\text { and British usage during my reading the text books. }\end{array}$ & 231 & 304 & 7 & 39 & 19 & 4.15 & .96 \\
\hline 5 & $\begin{array}{l}\text { While reading the literature, I do not get a chance to } \\
\text { improve and extend the use of communication strategies } \\
\text { in the language. }\end{array}$ & 134 & 345 & 12 & 96 & 13 & 3.82 & 1.023 \\
\hline 6 & $\begin{array}{l}\text { After preparing my lessons, I experience difficulty in } \\
\text { reading comprehension. }\end{array}$ & 45 & 292 & 4 & 220 & 39 & 3.14 & 1.182 \\
\hline 7 & $\begin{array}{l}\text { I can easily explain the given lines of a poem with } \\
\text { reference to the context. }\end{array}$ & 33 & 143 & 6 & 307 & 111 & 2.47 & 1.195 \\
\hline 8 & I can write the theme of a short story in my own words. & 39 & 248 & 7 & 243 & 63 & 2.93 & 1.223 \\
\hline 9 & $\begin{array}{l}\text { The teacher does not always encourage creative writing } \\
\text { in English class. }\end{array}$ & 70 & 284 & 19 & 204 & 23 & 3.29 & 1.163 \\
\hline 10 & $\begin{array}{l}\text { I can write a grammatically correct paragraph on any } \\
\text { topic given in the English class. }\end{array}$ & 20 & 107 & 5 & 341 & 127 & 2.25 & 1.082 \\
\hline 11 & $\begin{array}{l}\text { After having gone through the text, I cannot explain the } \\
\text { dialogues in my own words. }\end{array}$ & 66 & 334 & 5 & 172 & 23 & 3.41 & 1.128 \\
\hline 12 & $\begin{array}{l}\text { I cannot easily describe the different characters, scenes } \\
\text { and happenings which I come across in the text in my } \\
\text { own words. }\end{array}$ & 59 & 319 & 7 & 194 & 21 & 3.33 & 1.131 \\
\hline 13 & $\begin{array}{l}\text { To elaborate the literary terms in my own words is } \\
\text { difficult for me. }\end{array}$ & 91 & 381 & 6 & 111 & 11 & 3.72 & .994 \\
\hline 14 & $\begin{array}{l}\text { The language learnt through literature does not help me } \\
\text { in letter writing. }\end{array}$ & 89 & 328 & 11 & 154 & 18 & 3.53 & 1.114 \\
\hline 15 & $\begin{array}{l}\text { I can describe the summary of any poem or lesson in my } \\
\text { own words. }\end{array}$ & 27 & 193 & 8 & 275 & 97 & 2.63 & 1.213 \\
\hline
\end{tabular}

According to Harris (1993), writing is a cognitive ability not an innate and natural one. It requires strenuous effort and training. O' Rourke (2005) styles it a craft and career. To Evernett (2005), creative writing means original composition. It is a well-established fact that creative writing is accorded a great importance when the EFL learners are taught English through literature but it has also been observed that these learners are not given adequate classroom practice in creative writing. Table 5 shows that ESL/EFL learners' attitude towards the effect of their being taught English language on creative writing. For instance, 83\% cannot learn lexical 
appropriateness, $79.8 \%$ remain unable to improve and extend the use of communication strategies in the target language, $69.7 \%$ cannot explain the given lines of a poem with reference to the context, $77 \%$ remain unable to write a grammatically correct paragraph on any topic given in the English class, $66.7 \%$ cannot explain the dialogues in their own words, and $78.7 \%$ find themselves unable to elaborate the literary terms which they come across in their textbooks. The present study finds out that the textbooks do not help the EFL learners develop creative writing as $83.3 \%$ subjects of the study maintain that they do not get any help from the textbooks in honing their art of creative writing. About $80 \%$ of the respondents claim that they do not get any chance to improve and extend the use of communication strategies in the target language when they are taught English through literature. It has also been discovered that the FL educator does not always encourage creative writing in English class. It has also been found out that teaching English through literature does not enable the students to write a letter or describe the summary of a poem or lesson or explain the dialogue in their own words just because of the memorization of the ready-made material. In this respect, Borden (2001) seconds this issue when he claims that such an approach kills the students' creativity. Khan's (2011) study also corroborates the point raised in the present study when she claims that the EFL learners are not encouraged and motivated to pen down their own stories through the use of genre or process approaches. Mustafa (2009) also opines that the textbooks do not provide the EFL learners a chance for building their skill, communication and expression when they are not taught through either of the approaches: genre and process. In this respect, Borden (2001), too, believes that the way writing is taught in Pakistan kills the EFL learners' creativity. According to the collected data, 59\% respondents claim that creative writing is not encouraged in the language classroom. That's why the Pakistani EFL learners of intermediate level face problems when they have to do creative writing either in the classroom or in the examination hall. These findings of the present study also relate with those of an earlier study conducted by Warwick \& Reimers (1995) which also maintains that unmotivated approach of the faculty and students, curriculum and memorization are such factors as leave no room for creative writing in language class. That's why we find Cummins (2009) convinced of the role of a teacher in enhancing the EFL learners' skill of creative writing when he invites the college professors to integrate writing assignments into the curricula so that the EFL learners' skill in originality may be developed. Another study carried out by Siddiqui (2007) also seconds this opinion by saying that fixed syllabus, lack of resources, untrained teachers and large classes are the factors which go against the Pakistani EFL learners' developing and practicing creative writing.

Table 9. Correlation between achievement test and ESL learners' attitude towards teaching creative writing through literature

\begin{tabular}{lll}
\hline & Creative Writing & Achievement Test \\
\hline Pearson Correlation & 1 & $-.082^{*}$ \\
Sig.(2-tailed) & & .044 \\
$\mathrm{~N}$ & & 600 \\
\hline
\end{tabular}

Note.*. Correlation is significant at the 0.05 level (2-tailed).

Table 9 shows that there is a negative correlation between the ESL learners' attitude towards teaching creative writing through literature and the achievement test $(\mathrm{r}=-.082, \mathrm{p}<.05)$.

Table 10. Writing proficiency level of the ESL/EFL learners

\begin{tabular}{lllll}
\hline S. No. & Scale Score & Competence Level & No. of Participants & Percentage \\
\hline 1 & $00-30$ & 1 & 75 & 12.5 \\
2 & $31-50$ & 2 & 199 & 33.2 \\
3 & $51-70$ & 3 & 153 & 25.5 \\
4 & $71-90$ & 4 & 94 & 15.7 \\
5 & $91-110$ & 5 & 35 & 5.8 \\
6 & $111-140$ & 6 & 19 & 3.2 \\
7 & $141-170$ & 7 & 15 & 2.5 \\
8 & $171-190$ & 8 & 7 & 1.2 \\
9 & $191-200$ & 9 & 3 & 0.5 \\
\hline
\end{tabular}

Table 10 illustrates $75(12.5 \%)$ participants are at level 1. It means that they are those students who are unable even to comprehend the test directions and the content of the test questions. In other words, the participants of 
this level need to develop their reading ability first let alone the writing skill.

The participants who fall at level 2 and 3 have very limited ability to express their opinion. Their expressions and responses are afflicted with serious disorganization, irrelevant specifics, frequent grammatical mistakes and inappropriate choice of lexical items. They are the 58.7\% (352) of the subjects of this study.

According to the table 6, there are $129(21.5 \%)$ of the subjects who have touched the competence level of 4 and 5. They are those who can give straight forward information and can express their opinion as they have some developing ability to this end. Inadequate and inappropriate explanations or details to support their opinion, inadequate organization, limited development of ideas, serious grammatical flaws, missing information and inconsistent grammatically correct sentences are the weaknesses which mark their expressions and responses.

It is interesting to note that $92.7 \%$ of the participants are those who range between competence level 1 and level 4. This bulk of huge percentage cannot give straight forward information, ask questions, give instructions, make requests and complete the assigned tasks successfully.

The participants at level 6 can give straight forward information, support their opinion with reasons, examples and explanations partially successfully. They are only $3.2 \%$ of the whole subjects of the study. However, the typical flaws at this level include not enough support and development for the main points and unclear connections between the points they make.

The writing skill of the participants of the competence level 7 is clear, coherent and effective when they accomplish the task of giving information, asking questions, giving instructions and making requests. Their writing presents relevant ideas. According to table 6, only 15 (2.5\%) out of 600 subjects are those who enjoy this level of competence.

The students who enjoy the writing proficiency level 8 are those who can communicate straightforward information effectively. They use reasons, examples or explanations to support their opinion. Moreover, their writing is clear, coherent, effective and well-organized. It is also characterized with variety of sentences appropriate choice of lexical items. This study shows that only $1.2 \%$ of the subjects have reached this level of writing proficiency. Whereas, the subjects who have proficiency level 9 regarding writing proficiency are just .5\% of the total subjects of this study. It means only .5\% are able to reach the set and required level of writing skill when they are taught language through literature. The writing of these learners' is well-organized and well-developed. Natural use of English, appropriate lexical choice, grammatical accuracy and variety of sentence structures are the salient features of these students' writing. The foregoing discussion about the ESL learners' proficiency level has been illustrated in the form of a pie chart given as follows:

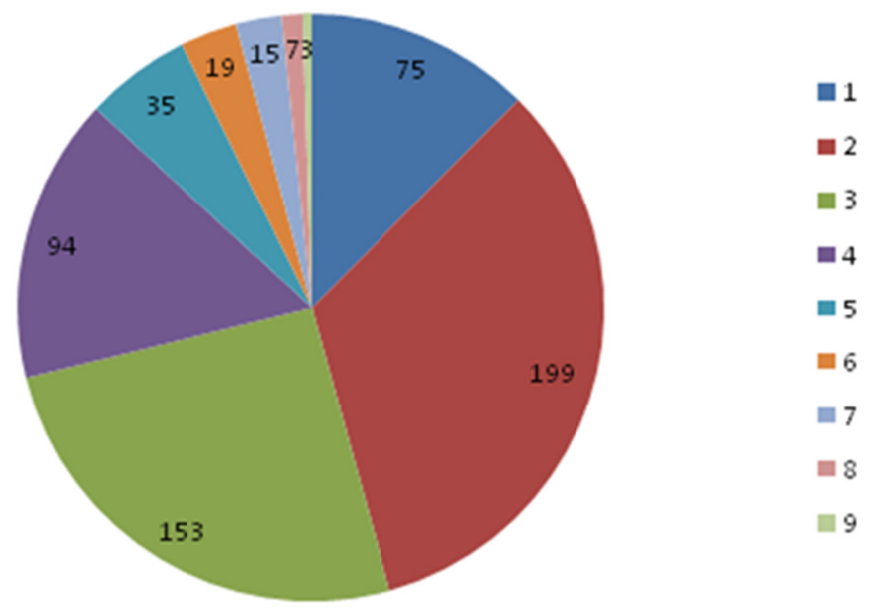

Figure 2. Illustration of ESL/EFL learners' writing proficiency level

\section{Conclusion}

In Pakistan, in order to develop the ESL learners' writing skill, radical decisions and paradigm shift are the most needed steps to be taken as there are many problems and challenges which render the textbooks an inadequate teaching resource. The most fatal among them are the prescriptive syllabus, teaching methodology, provision of ready-made material and the assessment system. Moreover, the selected textbooks are not used to develop and 
hone all the basic language skills-listening, speaking, reading and writing. It has also been observed that the teaching of English in Pakistan, specifically in state-run schools and colleges, is highly ritualized. The texts chosen to teach English through literature rarely deal with linguistic and grammatical sides.

\section{References}

Aghagolzadeh, F., \& Tajabadi, F. (2012). A Debate on Literature as a Teaching Material in FLT. Journal of Language Teaching and Research, 3(1), 205-210. https://doi.org/10.4304/j1tr.3.1.205-210

Ahmad, S., \& Rao, C. (2013). Applying Communicative Approach in Teaching English as a Foreign Language: A Case Study of Pakistan. PortaLinguarum, 20, 187-203.

Akram \& Mehmood. (2009). The Status and Teaching of English in Pakistan; Language in India. Strength for Today and Bright Hope for Tomorrow, 7(12).

Al-Dersi. (2013). The Use of Short-Stories for Developing Vocabulary of EFL Learners. IJ-ELTS: International Journal of English Language \& Translation Studies, 1(1), 72-86.

Ansari, M. S. (2013). Teaching Language through Literature in ESL/EFL Classes: A Critical Study in Utilitarian Perspectives. International Journal of English and Education, 2(3).

Borden, M. (2001). Creativity and Knowledge. In A. Craft, B. Seffrey, \& M. Liebling (Eds.), Creativity in Education. London: Continuum.

Bosher, S. (1998). The Composing Processes of Southeast Asian Writers at the Post-secondary Level: An Exploratory Study. Journal of Second Language Writing, 7, 205-240. https://doi.org/10.1016/S1060-3743(98)90013-3

Canale \& Swain. (1980). Theoretical Bases of Communicative Approaches to Second Language Teaching and Testing. Applied Linguistics, 1(27).

Cruz, J. H. R. (2010). The Role of Literature and Culture in English Language Teaching. Retrieved from $\mathrm{http}: / / w w w . r e l i n g u i s t i c a . a z a . u a m . m x / n o 007 / n o 07 \mathrm{art} 09 . \mathrm{html}$

Cummins, A. (2009). Tell Me a Story: Effective Use of Creative Writing Assignments in College Literature Courses. Currents in Teaching and Learning, 1(2), 42-49.

Daskalovska, N., \& Dimova, V. (2012). Why should literature be used in the language classroom? Procedia—Social and Behavioral Sciences, 46, 1182-1186. https://doi.org/10.1016/j.sbspro.2012.05.271

Deeba, M., \& Sultana, R. (2008). Literature-One of the best ways of teaching language. Daffodil International University Journal of Business and Economics, 3(1).

Dorn, D. (2000). Building Essays: A Reader Centered Writing Guide. New Jersey: Prentice Hall.

Dornyei, Z. (2011). Research Methods in Applied Linguistics. Qualitative, Quantitative and Mixed Methodologies. Oxford: Oxford University Press.

Evernett, N. (2005). Creative Writing and English. The Cambridge Quarterly, 34(3), 231-242. https://doi.org/10.1093/camqtly/bfi026

Ghani, M. (2003). The Status and Position of English Language in Pakistan. Journal of Social Sciences and Humanities, 1(1).

Harlan, K. (2000). Foreign Language Textbooks in the Classroom: Bridging the Gap between Second Language Acquisition Theory and Pedagogy. Honors Project. Paper 5. Retrieved from http://digitalcommons.iwu.edu/hispstu_honproj/5

Harmon et al. (2009). Promoting Vocabulary Learning with the Interactive Word Wall. Middle School Journal, 40(3), 58-63. https://doi.org/10.1080/00940771.2009.11495588

Harris, J. (1993). Introducing Writing. London: Penguin Books Ltd.

Hulstijn, J. H., \& Laufer, B. (2001). Some Empirical Evidence for the Involvement Load Hypothesis in Vocabulary Acquisition. Language Learning, 51, 539-558. https://doi.org/10.1111/0023-8333.00164

Khan, H. I. (2011). Testing Creative Writing in Pakistan: Tensions and Potential in Classroom Practice. International Journal of Humanities and Social Science, 1(15).

Khatib, D., \& Rezaei. (2011). Why \& Why Not Literature: A Task-Based Approach to Teaching Literature. International Journal of English Linguistics, 1(1). https://doi.org/10.5539/ijel.v1n1p213 
Kunwar, N. (2013). Literature in Classrooms: Practices and Reflection. FORTELL, 26, 20-22.

Lee, S. H., \& Muncie, J. (2006). From Receptive to Productive: Improving ESL Learners' Use of Vocabulary in a Post Reading Composition Task. TESOL Quarterly, 40, 295-320. https://doi.org/10.2307/40264524

Leki, I., \& Carson, J. G. (1994). Students' Perceptions of EAP Writing Instruction and Writing Needs across the Disciplines. TESOL Quarterly, 28, 81-101. https://doi.org/10.2307/3587199

Mashori, G. M., \& Lal, C. (2011). Developing a Teaching Program for the Students of English with Low Ability in Writing. Australian Journal of Basic and Applied Sciences, 5(5), 1119-1127.

McKay, S. (1982). Literature in the ESL Classroom. TESOL Quarterly, 16(4), 529-536. https://doi.org/10.2307/3586470

Mustafa, S. (2009). The Importance of an Examining Board. Retrieved from http://www.education@dawn.com

Nam, J. (2010). Linking Research and Practice: Effective Strategies for Teaching Vocabulary in the ESL Classroom. TESL Canada Journal/Revue TESL Du Canada 129, 28(1), 127-135. https://doi.org/10.18806/tesl.v28i1.1064

Nayan, S. (2009). A Study of Subject-Verb Agreement: From Novice Writers to Expert Writers. International Education Studies, 2(3). https://doi.org/10.5539/ies.v2n3p190

O’Rourke, R. (2005). Creative Writing: Education, Culture and Community. Plymouth: Latimer Trend.

Pardede, P. (2011). Using Short Stories to Teach Language Skills. Journal of English Teaching, 1(1), 14-27.

Pathan, M. M., \& Al-Dersi, Z. E. M. (2013). Investigating the Role of Short-Stories in Overcoming the Problems Faced by the Libyan EFL Learners in Reading Comprehension Skill. The Criterion An International Journal.

Premawardhena, N. C. (2006). Integrating Literature into Foreign Language Teaching: A Sri Lankan Perspective. Novitas-ROYAL, 1(2), 92-97.

Reinders, H., \& Balcikanli, C. (2011). Do Classroom Textbooks Encourage Learner Autonomy? Novitas-ROYAL (Research on Youth and Language), 5(2), 265-272.

Sakthivel, V., \& Kavidha, N. (2010). Is Literature a Viable Medium for ESL Acquisition? Language In India: Strength for Today and Bright Hope for Tomorrow, 10(1).

Shuib, S. (1991). An analysis of Malaysian learners' English Agreement Errors. University of Essex.

Siddiqui, S. (2007). Rethinking Education in Pakistan: Perceptions, Practices, and Possibilities. Lahore: Paramount Publishing Press.

Swales, J. M., \& Feak, C. B. (1994). Academic Writing for Graduate Students: Essential Tasks and Skills. Ann Arbor: University of Michigan Press.

Warwick, P., \& Reimers, F. (1995). Hope or Despair: Learning in Pakistan's Primary Schools. Santa Barbara, California: Praeger Publishers.

\section{Copyrights}

Copyright for this article is retained by the author(s), with first publication rights granted to the journal.

This is an open-access article distributed under the terms and conditions of the Creative Commons Attribution license (http://creativecommons.org/licenses/by/4.0/). 